\title{
Common structural and construction deficiencies of Nepalese buildings
}

\author{
Dipendra Gautam $^{1}$ - Hugo Rodrigues ${ }^{2}\left(\right.$ He $^{-}$Krishna Kumar Bhetwal $^{1,3}$. \\ Pramod Neupane $^{4} \cdot$ Yashusi Sanada $^{5}$
}

Received: 21 October 2015/Accepted: 15 February 2016/Published online: 29 March 2016

(C) Springer International Publishing Switzerland 2016. This article is published with open access at Springerlink.com

\begin{abstract}
This paper outlines the common observed failure patterns in the buildings of Nepal after $\mathrm{M}_{\mathrm{W}} 7.8$ Gorkha (Nepal) earthquake. Several types of damage patterns were observed for reinforced concrete buildings, as well as for unreinforced masonry and adobe houses during the reconnaissance survey performed immediately after the earthquake of 25 April 2015. Several field visits in the affected districts were conducted and associated failure/damage patterns have been identified and analyzed. This paper also covers damage patterns in non-engineered buildings, middle and high-rise buildings, commercial complexes, administrative buildings, schools and other critical facilities from Kathmandu valley as
\end{abstract}

Dipendra Gautam

strdyn@yahoo.com

Hugo Rodrigues

hugo.f.rodrigues@ipleiria.pt

Pramod Neupane

pneupane0124@gmail.com

Yashusi Sanada

sanada@arch.eng.osaka-u.ac.jp

1 Structural and Earthquake Engineering Research Institute, Kathmandu, Nepal

2 RISCO - School of Technology and Management, Polytechnic Institute of Leiria, Leiria, Portugal

3 Institute of Industrial Science, The University of Tokyo, Tokyo, Japan

4 Urban Governance and Development Program (UGDP), Dhankuta Municipality Office, Dhankuta, Nepal

5 Department of Architectural Engineering, Division of Global Architecture, Graduate School of Engineering, Osaka University, 2-1 Yamadaoka, Suita 565-0871, Osaka, Japan well as other affected districts. The construction and structural deficiencies are identified as the major causes of failure, however local soil amplification, foundation problems, liquefaction associated damages and local settlement related damages are also significantly observed during this earthquake and reported in the present paper. In the end, the lessons learned from the field survey are resumed in order to give some guidelines for future construction practices.

Keywords Structural damage $\cdot$ Reinforced concrete structure - Unreinforced masonry building - Adobe house . Gorkha earthquake $\cdot$ Nepal

\section{Background}

On 25 April 2015 a strong earthquake of $\mathrm{M}_{\mathrm{W}} 7.8$ hit central Nepal and its vicinity [1] causing 8790 casualties and 22,300 injuries [2]. Around 755,549 residential buildings, 4000 government offices, and 8200 school buildings are damaged due to this earthquake [2]. The hypocentral depth was about $15 \mathrm{~km}$ and it was immediately followed by strong aftershock of $\mathrm{M}_{\mathrm{W}}$ 6.7. The earthquake was located at Gorkha district of western Nepal near the Barpak village around $77 \mathrm{~km} \mathrm{NW}$ of Kathmandu. A strong aftershock of $\mathrm{M}_{\mathrm{W}} 7.3$ also jolted central Nepal on 12 May which further enhanced the damage and casualties. Nearly 8 million people from central and eastern Nepal were affected by this earthquake and several hundreds of aftershocks everyday for around 3 months. Six out of the fourteen districts in Nepal were severely damaged causing enormous property and infrastructural collapse. People remained outside their house under tarpaulins/tents for around a month due to frequent aftershocks and fragile structures. 
A general description of Nepalese building construction frameworks and associated deficiencies in terms of structural as well as construction scenario has been discussed in this paper. Furthermore, this paper attempts to correlate the building damage pattern associated with structural and construction deficiencies. Moreover, the failure types and identified causes are presented drawing conclusions from extensive field reconnaissance in 11 districts out of 14 affected districts on central Nepal.

\section{Overview of housing construction in Nepal since 1934}

Building construction in Nepal dates back to several thousand years, though the reminiscent of bricks from Buddha's period are the most reliable sources. It could be said that before 2550 years, there used to be masonry construction system in Nepal. Most of the traditional settlements of Kathmandu valley are of around thirteenth century and the history of villages dates back to similar time. The adobe construction, wooden framed houses and rubble stone masonry constructions are more popular in villages of Nepal, meanwhile most of the urban and suburbs constitute majority fraction of stone or brick masonry buildings constituting around $20 \%$ of reinforced concrete (RC) construction. So, it is obvious that $80 \%$ of the buildings are non-engineered to poorly engineered stone or brick masonry constructions even in urban areas of Nepal; moreover, majority fraction of RC construction is also covered by non-engineered to pre-engineered construction as owner built houses [3]. The description presented by Brahma Shamsher Rana in his book "The Great Earthquake of Nepal" [Nepal ko mahabhukampa (in Nepali)] depicts the prevalence of widespread stone and brick masonry structures. Notably, the bricks were of both burnt and non-burnt clay units in absence of mechanized system. Similarly, the stone masonry houses in villages of Nepal were also reported in his work along with significant fraction of wooden framed structures in rural Nepal. The performance of masonry structures was noticeably inferior than the performance of wooden framed structures during 1934 earthquake due to construction technology, load concentration and structural binding as well as large number of masonry structures in comparison to wooden framed structures. In addition to this, masonry houses in Nepal are used at least by three generations without any strengthening measures, so during every earthquake in Nepal the older masonry structures claim enormous damage of life and properties. Similarly, during 1988 earthquake in Nepal building units were commonly of adobe, wooden framed, brick or stone masonry and very small number of RC structures [4]. The reconnaissance report presented by JSCE depicts the severity of damage in adobe and masonry houses in eastern and central Nepal with relatively insignificant damage in wooden framed and $\mathrm{RC}$ structures. Moreover, the masonry houses collapsed during the 1988 earthquake were primarily the survivors of 1934 earthquake [4]. Similarly, it is widely noted that majority of the collapsed masonry houses in rural as well as urban areas of Nepal were either the survivors of 1988 earthquake or even 1934 and 1988 earthquake [5]. After 1980s RC construction in Nepal has been mushrooming and surpassed any other construction types after 2000 in urban areas. However, in rural Nepal stone masonry, adobe and wooden framed structures are still being dominant construction types. The construction technology, construction materials, binding materials are not significantly changing in rural settlements of Nepal. In contrast, the urban housing stocks are nowadays constructed either following by-laws, mandatory rule of thumb as suggested by Nepal Building Code or well designed structures with analysis and ductile detailing frameworks. After enactment of Building Code Act (1994) and legal enforcement in 2003, the urban housing construction has significantly progressed in terms of building composition and design based on seismic demand. Yet, the majority fraction of structures in Nepal are the ones constructed before enforcement of building codes, so structural vulnerability hasn't been reduced significantly. In the other hand, however the Nepal Building Code suggests some strengthening techniques for rural construction, technology transfer and adoption of improvement mechanisms are largely lagging.

Past studies have shown the vulnerability of buildings to be very high and predicted severe damages in case of strong to major earthquake in central and western Nepal [6-10]. Most of the RC buildings constructed after 1980 are of 2-6 stories with exception of a few 7-11 storied high rise structures. The trend of $\mathrm{RC}$ construction is being more popular than any other construction types though economic constraints, availability of construction materials and technology, lack of optimized design, lack in enforcement of building regulations are some of the loopholes that are degrading the quality of construction ultimately increasing vulnerability of buildings. Regarding other types of structures, it is obvious that older and nonengineered constructions are enhancing the vulnerability. With exception to some severe but localized damages in $\mathrm{RC}$ buildings, most of the damage was concentrated in masonry, and adobe constructions during 2015 Gorkha earthquake in Nepal. This earthquake also correlates with the severe damage of unreinforced masonry (URM) structures during 1934 earthquake [11] and also the damage patterns are similar for many urban fabrics and outskirts. 

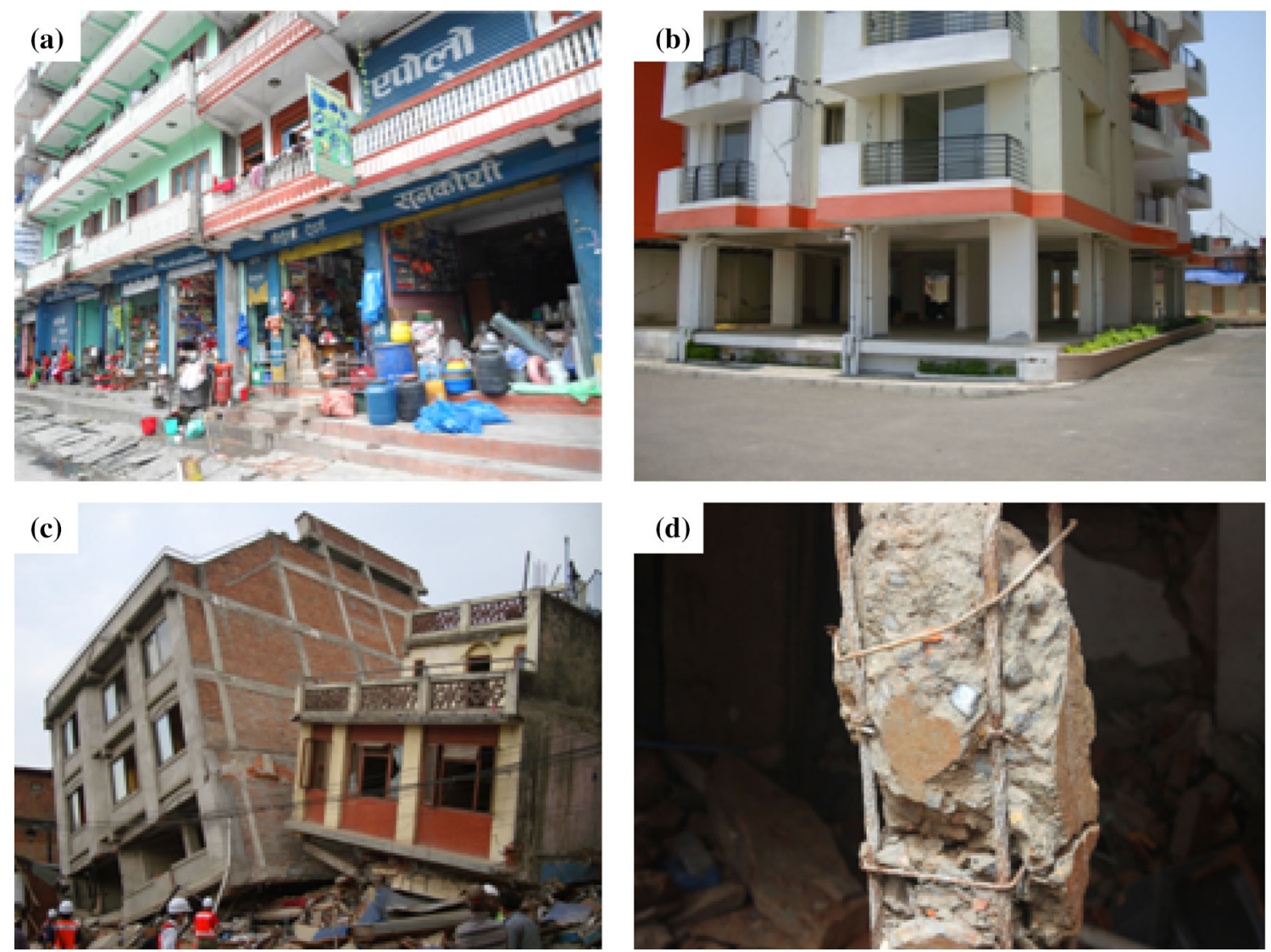

Fig. 1 a Ground floor of residential buildings without infill walls. b Ground floor of an apartment building without infill wall. c Soft storey and structural pounding failure. d $16 \mathrm{~mm}$ diameter rebar but only four in number (corroded as well) from a collapsed building in Kathmandu

\section{General context of reconnaissance}

Immediately after the earthquake of 25 April, many field observations were carried out within and outside the Kathmandu valley. Affected districts namely; Kathmandu, Lalitpur, Bhaktapur, Kavrepalanchowk, Sindhupalchowk, Dolakha, Nuwakot, Gorkha, Dhading, Solukhumbu, Makwanpur, Tanahun and Kaski were covered in field visits at different times in between 26 April and 25 June 2015. The damaged buildings were analyzed in terms of construction history, structural adequacy, building components, binding materials and adopted technology for construction. Non-structured interviews were conducted during reconnaissance and associated failure types were pictured. The pictures were analyzed for identifying the causes of failure. The reconnaissance covered mainly four types of building; RC, URM, rubble stone construction and adobe houses. As completely wooden framed houses were not identified during reconnaissance, performance of those four types of buildings was judged on the basis of common structural and construction deficiencies.

\section{Structural and construction deficiencies and associated damages in buildings during 2015 Gorkha earthquake}

\section{Construction and structural deficiencies and associated damages in $\mathrm{RC}$ buildings}

About $10 \%$ of buildings in Nepal are RC buildings [3]. The construction of RC buildings only started after 1980; however the mushrooming number of RC construction was started only after 1990. Even though the RC construction was started in early 1980s, engineered construction was only felt after enforcement of building codes in 2006 and almost $70 \%$ of existing RC buildings are either owner built constructions constructed with the help of contractors following by-laws or constructed as per the mandatory rules of thumbs as suggested by Nepal Building Code [2]. Smaller fraction of buildings are structurally analyzed, designed and constructed. After more localized concentration of RC building damage during 2015 Gorkha earthquake, several field visits and case studies have reflected many of the deficiencies associated with 

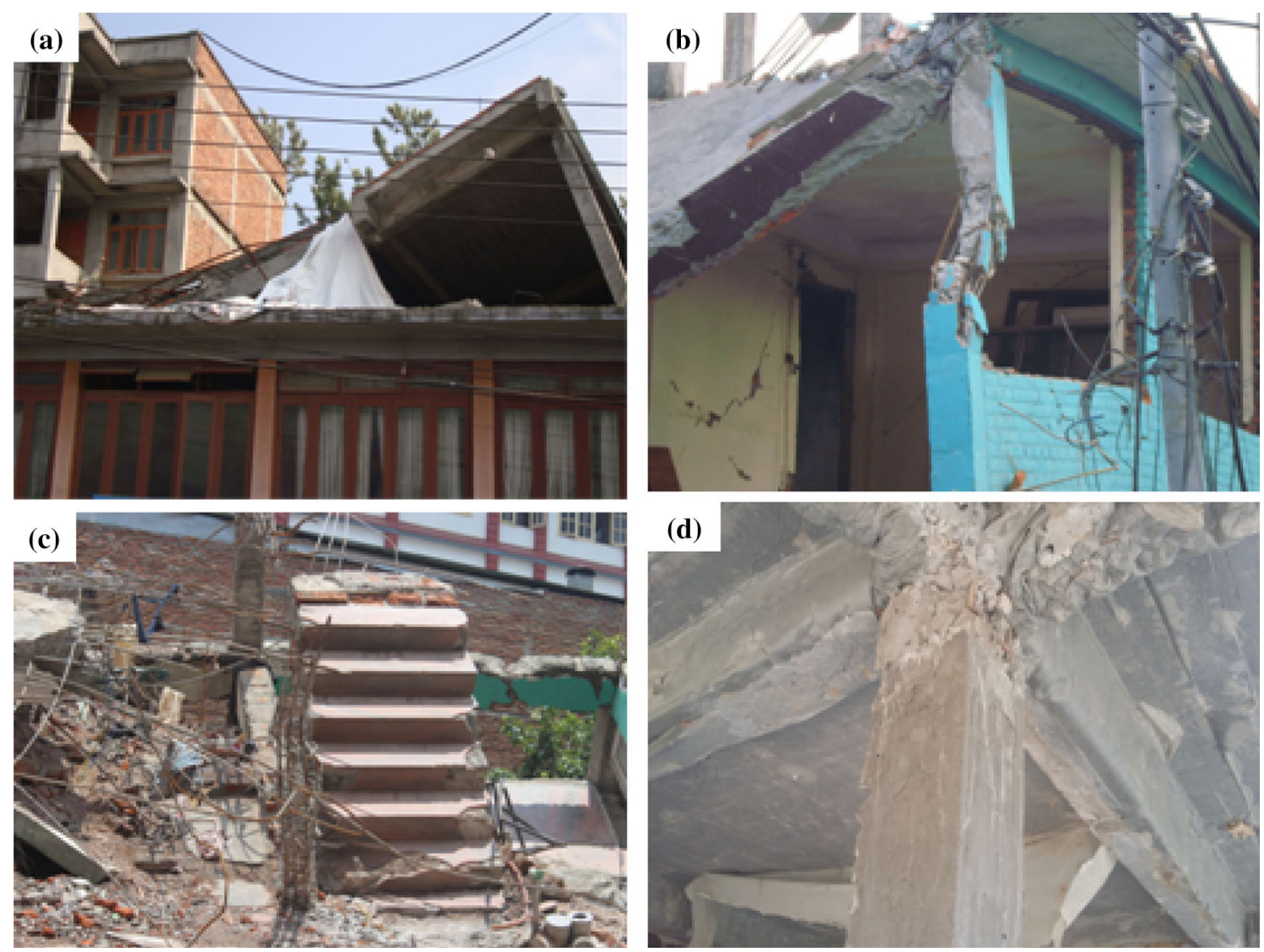

Fig. 2 a Collapsed column due to welded vertical re-bars. b Column failure due to large gap of stirrups. c Outwardly placed $6 \mathrm{~mm}$ diameter rebars exposed on collapsed structures. d Poor beam column connection with exposed re-bars

construction or structural aspects have been highlighted in recent dates. Common structural and construction deficiencies and associated damages as observed during field reconnaissance performed after the earthquake are summarized in following sections.

\section{Soft storey}

During the field study performed immediately after the 2015 Gorkha earthquake, it is observed that soft storey failure in RC buildings is one of the most common causes of collapse, among with other type of structural deficiencies. The common type of building framing is moment resisting with monolithic slab cast in beams and columns. The foundation type usually adheres as isolated footing in residential level and combined mat and pile foundation for most of the high rise apartment buildings. The ground floor in almost $90 \% \mathrm{RC}$ buildings is used for commercial purpose and provided with shutters (Fig. 1a), however the upper stories of such buildings are provided with infill brick masonry walls. Similarly, in case of high rise constructions, the ground floor are left open for parking or sometimes basement parking is provided without infill walls (Fig. 1b). Such practices have led the soft storey failure during 2015 earthquake in most of the damaged RC buildings (Fig. 1c). In addition to this, it was observed that most of the buildings in residential level were found to be practicing "weak column-strong beam" as depicted by the massive beams and smaller columns during field reconnaissance. Due to lack of infill wall on ground floor, the increased flexibility has significantly triggered the increased displacement in ground floor thus majority of the cracks or minor to severe damages were found to be concentrated therein during reconnaissance.

\section{Longitudinal reinforcement detailing}

The longitudinal rebar's are mostly limited to $12-16 \mathrm{~mm}$ diameter and usually in four to eight in numbers. In most of the collapsed buildings, the longitudinal rebar's were usually four, however majority of the building columns were found to be constructed with six rebar in vertical direction. The intense damage was significantly governed by the horizontal re-bars (stirrups). The stirrups were found to be $6 \mathrm{~mm}$ diameter bars usually gaped in regular interval of $0.15 \mathrm{~m}$ or more and in some cases (Fig. 1d), such gap was measured up to $0.40 \mathrm{~m}$. 
Reinforcement in infill walls were not found to be provided in residential constructions with exception to some apartments. Due to lack of reinforced walls in most of the brick kiln chimneys, almost all chimneys suffered from partial to complete collapse in Kathmandu valley [12]. More significantly, the connection between the structural components was also found to be poor. In some cases, it was observed that people preferred welding for connection of vertical reinforcements rather than anchoring thus failures were observed in those columns (Fig. 2a). The larger gap of stirrups was noticed to be significantly contributing in the failure of columns (Fig. 2b). Moreover, the structural damage and building collapse was found to be more governed by too less, smaller diameter and tying the vertical re-bars outwardly (Fig. 2c). Similarly, the beam column connection and layout of the reinforcement was found to be random leading to minor to serious damages. The workmanship defect along with the connection deficiencies were widely observed (Fig. 2d).

\section{Floating columns}

In order to cover up maximum area, upper stories are constructed more in balconies. In such practices, floating columns from first storey were commonly observed in residential construction within as well as outside Kathmandu valley (Fig. 3a). The floating columns are frequently used for increasing the built up area from upper stories (Fig. 3b). Due to lack of continuous load path during earthquakes, the lateral forces are not effectively transferred to the foundation. The overturning forces developed lead to buckle the columns of ground floor and subsequent damage was noticed in some buildings (Fig. 3c). Due to poor mechanism of construction monitoring, many of the urban constructions were noticed to be haphazardly increasing the housing size beyond structural system (Fig. 3d). Figure 3d is a residential construction in Lalitpur sub-metropolitan city which is taken as the successful example of building code implementation framework in Nepal, however the enforcement of building code was not found to be effectively monitored.

\section{Concrete mixing and placement}

In residential construction, the MRT has provisioned the minimum crushing strength to be $15 \mathrm{MPa}$ as per NBC 205 [2], though due to insufficient mixing, placement and workmanship the strength is not assured. Segregation and bleeding were
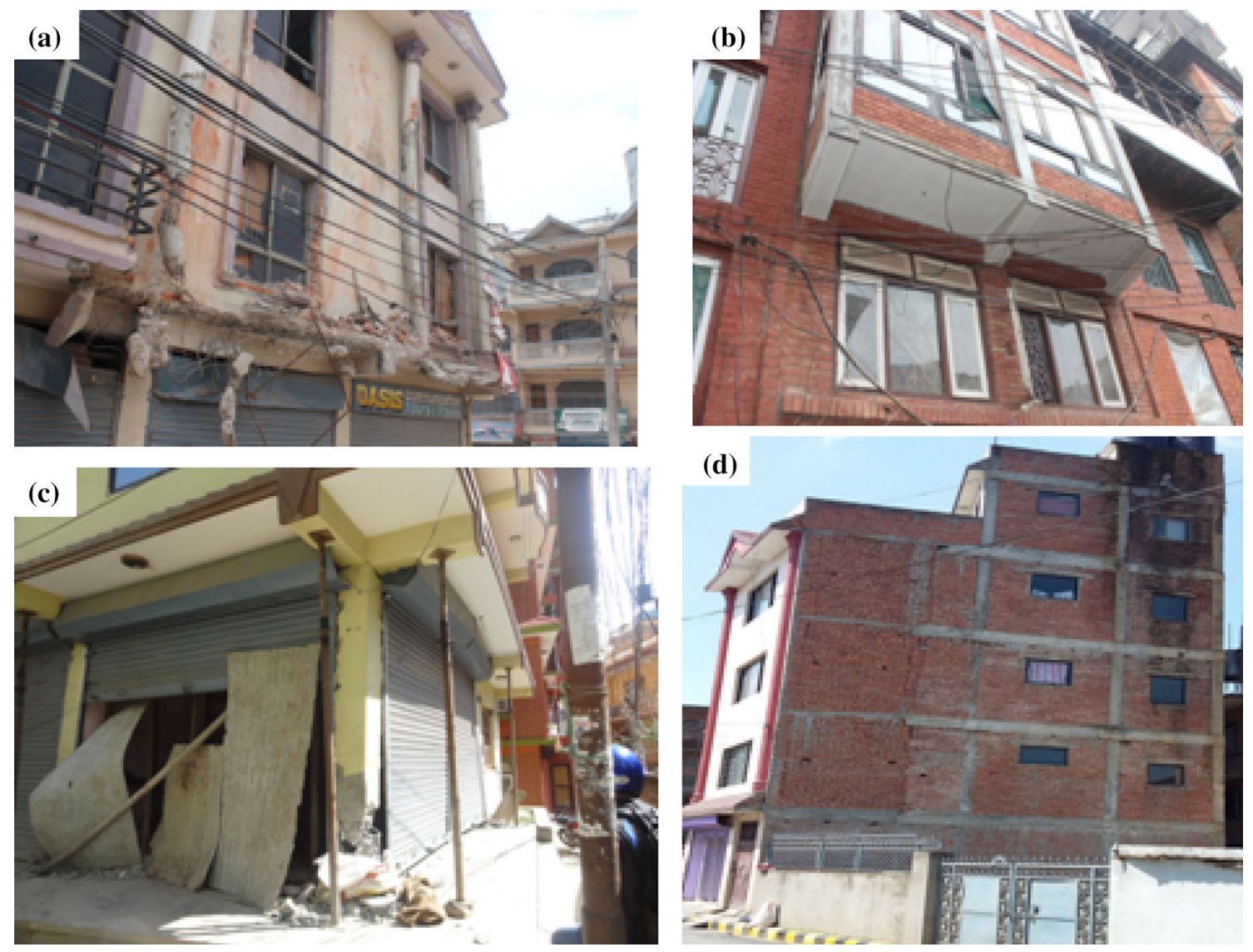

Fig. 3 a Floating column with projected construction in upper stories. b Floating columns and continued construction in upper stories. c Column buckling in a building with cantilevered construction and floating column. d Large cantilevered construction projected from structural system 
commonly observed in the damaged buildings. Quality of fine and coarse aggregates, water cement ratio significantly affect the strength of concrete, however in Nepal water cement ratio is usually exceeded for achieving workability compromising strength of concrete (Fig. 4a). In most of the damaged houses, corrosion of re-bars was recurrently visible. Use of rounded aggregates and poor binding was also exposed in some buildings outside Kathmandu valley (Fig. 4b). Rounded aggregates have led in poor stiffness and improper binding with concrete causing the out of plane failure.

Majority of the RC buildings in Nepal are constructed in phase, in this regard the variation in quality of construction materials and technology. This has led in non-homogenous and non-monolithic construction showing wider variation in terms of structural performance. It has been observed in around $80 \%$ of buildings with minor cracks to major damage was constructed in phase.

\section{Building asymmetry and other deficiencies}

Building asymmetry in terms of plan as well as elevation is more common in Nepal. Due to unavailability of spaces for construction, slender structures are also frequent in urban neighborhoods (Fig. 4c). Nepal building codes restrict the height to breadth and length to breadth ratio less than 3 [2], though these regulations are not properly enforced and monitored even in the only one metropolitan city of Nepal (Fig. 5a). Due to lack of construction monitoring system, owners add stories themselves hiring local contractors. In addition to slender structures, asymmetrical structures constructed following the shape of the land plot are more common in Nepal and such structures sustained heavy damage during 2015 Gorkha earthquake (Fig. 5b). In the outskirts of Kathmandu valley, the localized damages are more intense. Previously those areas used to be the villages or suburbs so that only mandatory rules of thumbs (NBC, 205) or experience of the local level contractors were effective as construction guideline. However due to lack of monitoring, owners themselves constructed some more stories without design approval, at the meantime such buildings were observed to be facing severe damages or even collapse. Before implementation of MRT, $0.23 \times 0.23 \mathrm{~m}$ was commonly adopted as the column size, however it provided as guideline for up to three stories in
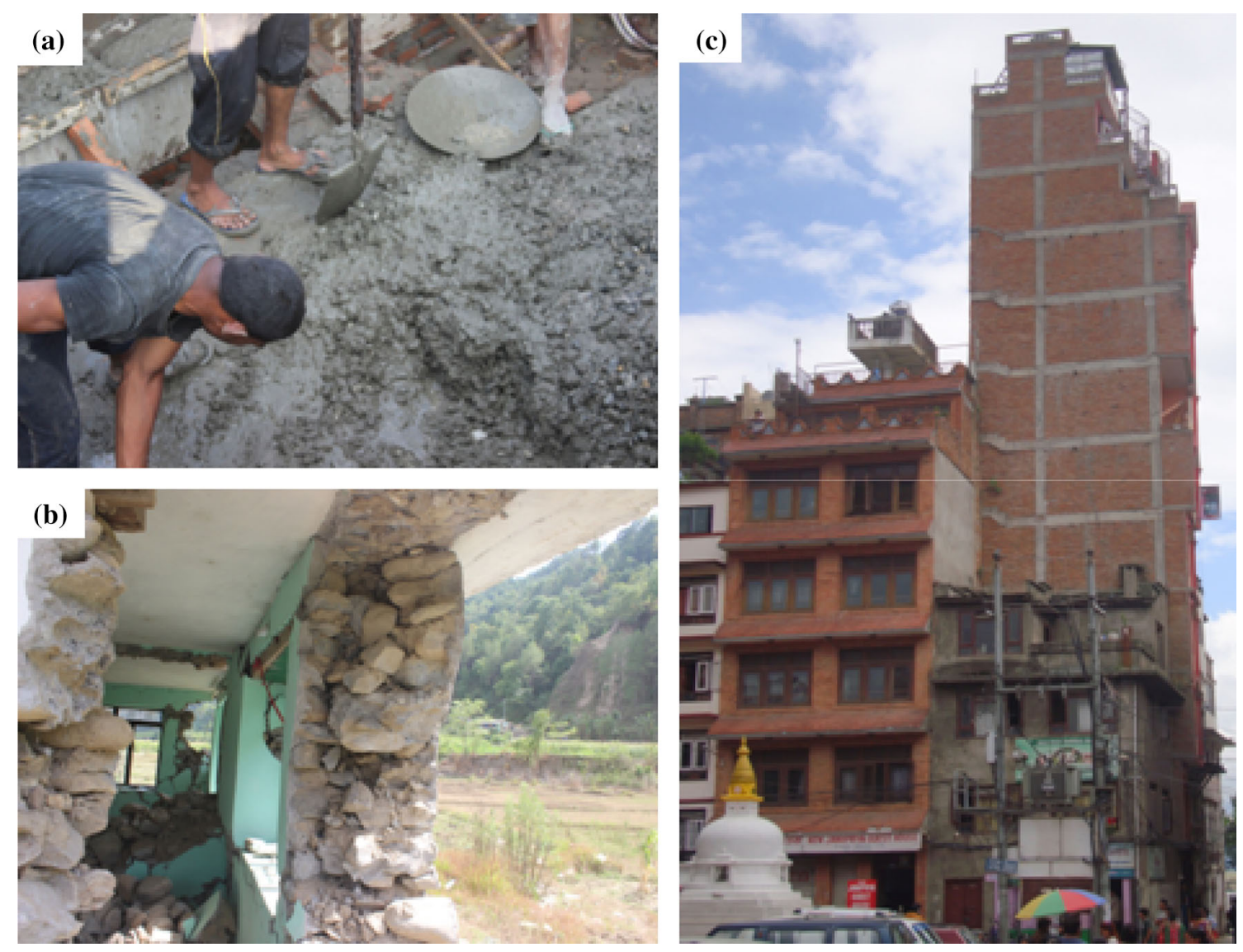

Fig. 4 a Common concrete mixing method with high water cement ratio in residential constructions. b Damaged wall due to improper binding on rounded aggregates in Melamchi (Sindhupalchowk). c An example of slender structure in Kathmandu metropolitan city 

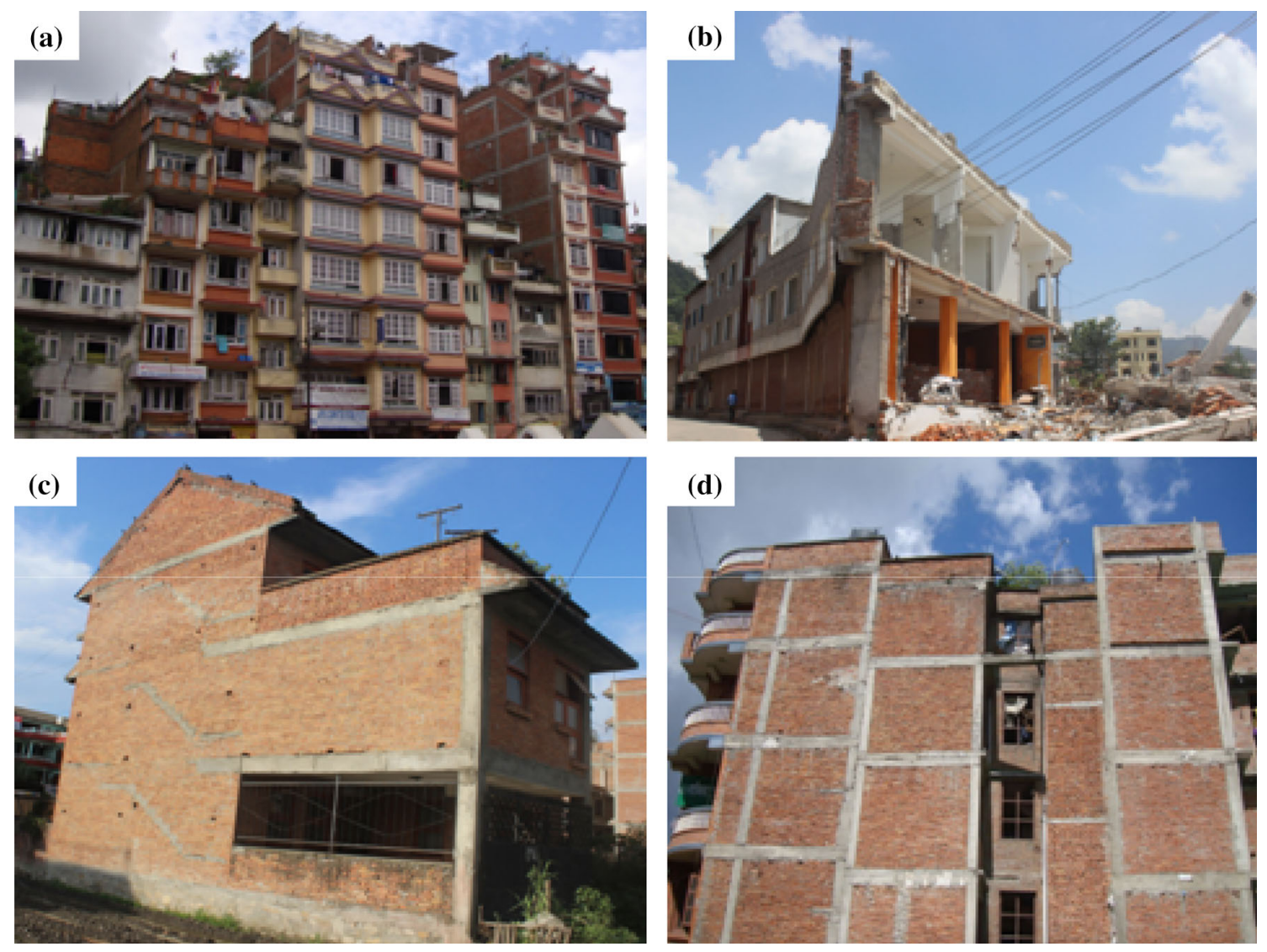

Fig. 5 a A neighborhood in Kathmandu metropolitan city with dominance of slender structures. b Asymmetric building with severe damage in Kathmandu. c Columns too less and not even in grid.

Nepal. Later, with the commercialization of areas, houses with the same column size were made up to seven stories. This was the significant cause for damage in most of buildings in Nepal during 2015 Gorkha earthquake. In addition to this, several houses were found to be constructed with combination of load bearing walls and columns (Fig. 5c), in doing so, it was observed that columns were too less and heavy RC slabs were provided for load bearing wall system. In some sites of Kathmandu valley, some of the construction flaws like joining masonry as well as RC buildings were observed (Fig. 5d).

\section{Load accumulation in upper stories}

In some locations of Kathmandu valley, traditional masonry houses were found to be added with reinforced concrete construction in third or four storey (Fig. 6a). Many of the buildings in Kathmandu are constructed with higher load concentration in upper stories and reducing the column size while constructing upper stories (Fig. 6b). Water tanks were found to be installed in every RC building in Nepal for gravity distribution in taps, though the weight of water tank was found to be nevertheless d Two RC buildings connected with a beam and one masonry building in between at Bhaktapur

accounted during structural analysis and design before construction even if it was obvious to install. At least one to five water tanks of varying capacity were found to be installed during field reconnaissance (Fig. 6c). Due to continuation of single column for water tank and construction of short column, some of the buildings sustained damages in those structures (Fig. 6d). Also in some houses, the load of telecommunication tower was found to be established without any structural analysis and design.

\section{Building interaction}

Due to close proximity of buildings in Kathmandu valley and other affected parts of Nepal, pounding solely or with several combinations with pounding has led moderate to severe damages in building (Fig. 7a). Due to wider variation in dynamic properties of adjoined buildings and unequal storey height, the pounding is observed intense in some areas where building proximity is common and adjoining buildings were constructed at different time with wider variation in construction materials, technology and workmanship. The major urban and sub-urban centers in Kathmandu valley have high built up area to total land plot, 

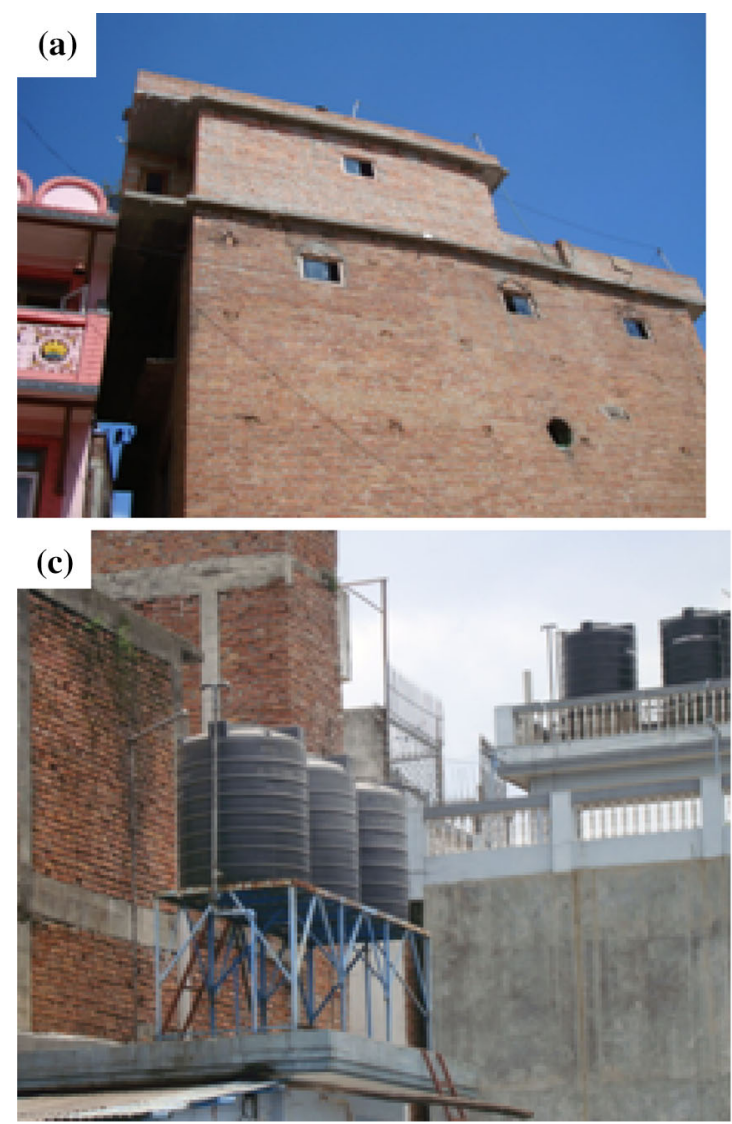

Fig. 6 a Plain cement concrete construction with RC slab above traditional masonry building. b Massive construction in upper stories and subsequent damage in ground floor. c Water tanks in Kathmandu

so almost all portion of land is covered by the structural system. Due to such close proximity led pounding, some structures were found to be separated some $3 \mathrm{~m}$ (Fig. 7b).

\section{Structural elements}

In columns, due to large spacing between the stirrups, weak column strong beam, insufficient development length of rebar, among others were found to be governing the damage concentration in columns. Plastic hinge formation (Fig. 7c) was also observed in some of the structures along with concrete spall caused due to buckled re-bars on ground floor (Fig. 7d).

\section{Non-structural elements}

In Nepalese RC construction practice, the infill walls are not accounted during design and analysis phase rather such walls are provided haphazardly through the knowledge of contractors or sometimes masons. Regarding the infill walls behavior in-plane and out-of plane damage was observed in several cases. The most
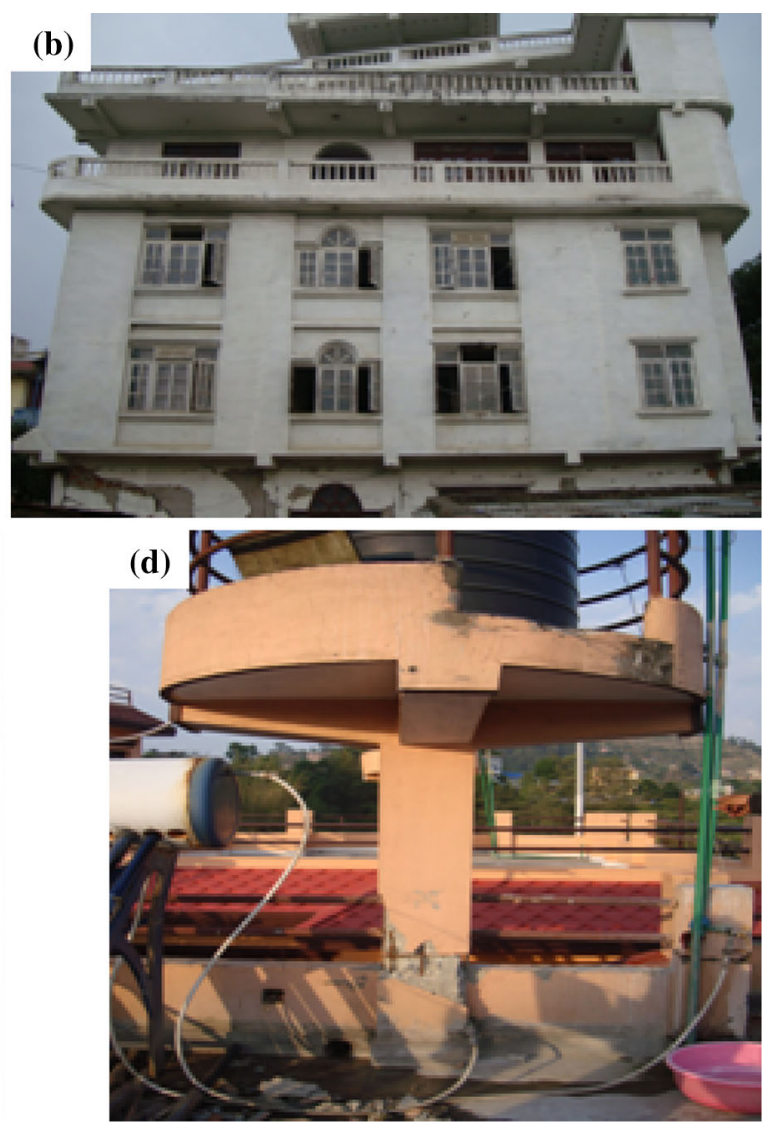

valley buildings. d Continued column from structural system damaged after Gorkha earthquake in a colony building

common failure of the non-structural element is related with the in-plane damage (diagonal and horizontal cracks), however it was also observed several case of out of plane failure of walls, most probably due to the combined effect of in-plane and out-of-plane behavior (Fig. 8a). Due to lack of anchorage between building diaphragm and infill walls, such failure was commonly observed during field reconnaissance. Infill walls have effectively contributed in damage with formation of captive column in many damaged RC buildings. The gross area of openings in infill walls is restricted to less than $10 \%$ in NBC [2] though for commercial purpose, most of the infill wall area is found to be covered by shutters or plywood separations.

Damages in staircase without proper anchoring with structural members was also noticed (Fig. 8b). Staircases could effectively perform as diagonal bracing members but due to lack of sliding joints in design most of the damage concentration was found to be in staircase. Also staircases are never isolated from structural elements as well, so the performance of buildings during earthquakes is also affected by the heavy staircases. 

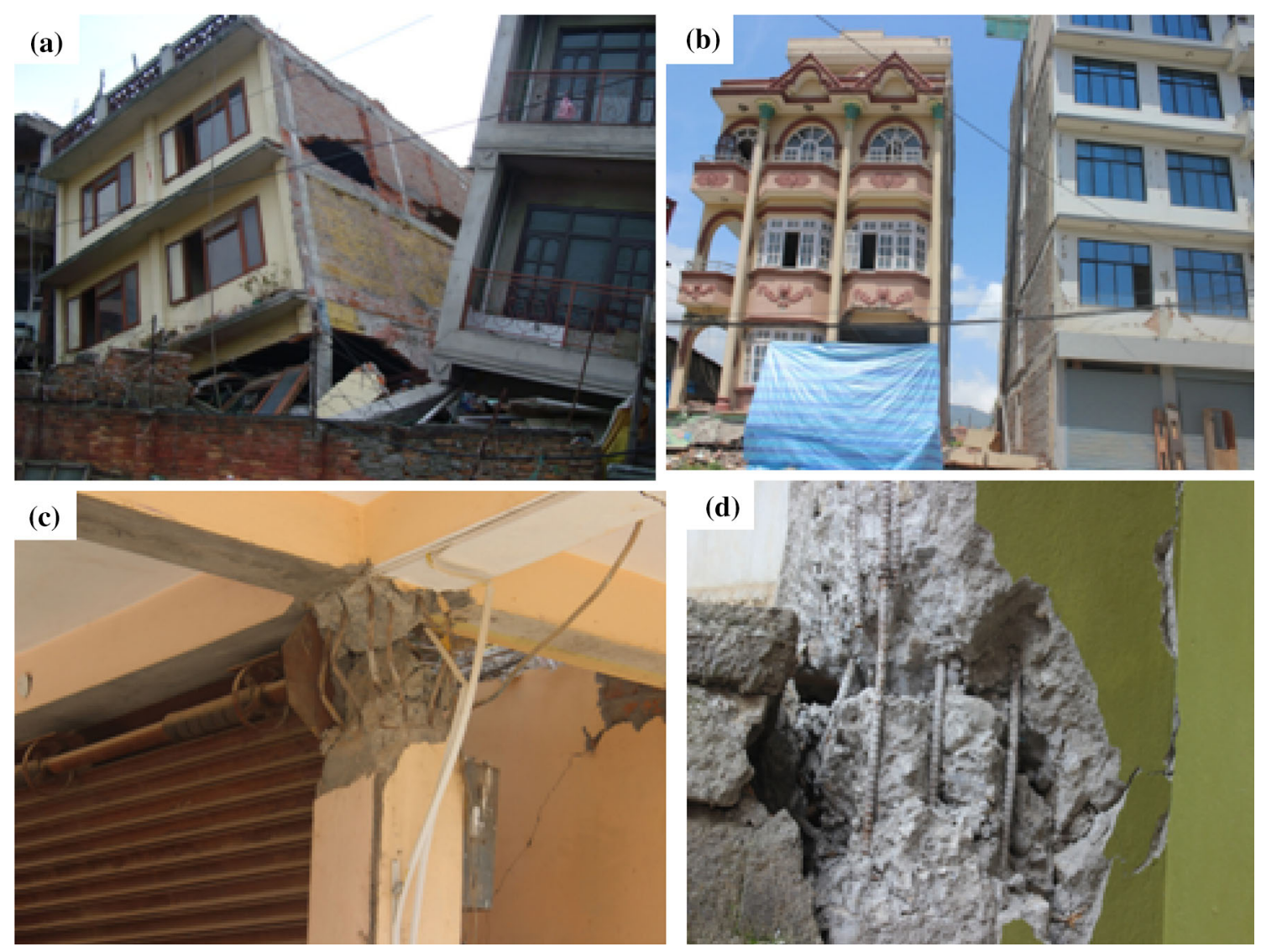

Fig. 7 a Collapsed buildings due to structural pounding in Gongabu (Kathmandu). b Structural pounding led displacement of building (3 m) in Sitapaila (Kathmandu). c Plastic hinge formation. d Base of first storey column with buckled rebar and concrete spall

Failure of water storage tanks was noticed during the reconnaissance (Fig. 8c). Water tanks are not accounted during building design and also it is found that owners themselves hire masons to construct water tanks. Moreover, there is no proper regulation to monitor how many water tanks a single building can install is not governed by any by-law or design code. Due to this fact, many houses in Kathmandu were found to be installing water tanks, heavy purification system and water heating systems.

Damage in parapet walls was observed in some RC buildings which were not reinforced and excessively high (Fig. 8d). The anchorage with roof diaphragm was found to be often lacking in case of damaged parapet walls.

The boundary walls were among the severely collapsed non-structural members during 2015 Gorkha earthquake (Fig. 8e). In order to separate property line or for security purpose, boundary walls were found to be constructed in almost every house within Kathmandu valley in newer settlements. However, in case of older settlements and outside Kathmandu valley boundary walls were not frequent. Due to poor workmanship and inferior quality of plain cement concrete construction proper binding was not assured so around
$90 \%$ of boundary walls with the thickness of $0.115 \mathrm{~m}$ fell in urban neighborhoods. In contrast, majority of the boundary walls with $0.23 \mathrm{~m}$ thickness survived significantly.

\section{Foundation problems}

Majority of constructions in Nepal follow the natural terrain relief for starting foundations. Thus for the inclined or terraced land, stepped foundation is more common (Fig. 9a). Isolated footing is the dominant foundation type and also it is observed that such footings are many on occasions placed in terraced construction site. Due to construction of footings in terraced land plot, numbers of footings were found to be varied in lower stories of structures. This ultimately led enhanced torsion in structural elements and damage is found to be concentrated in those buildings which are constructed in stepped foundation in Chautara, the most affected area in Sindhupalchowk district in central Nepal (Fig. 9b). As there is no trend of geotechnical observation and associated design variation in local scale in Nepal and many settlements are established on river banks, reclaimed sites and rice fields as well. During field reconnaissance, it 

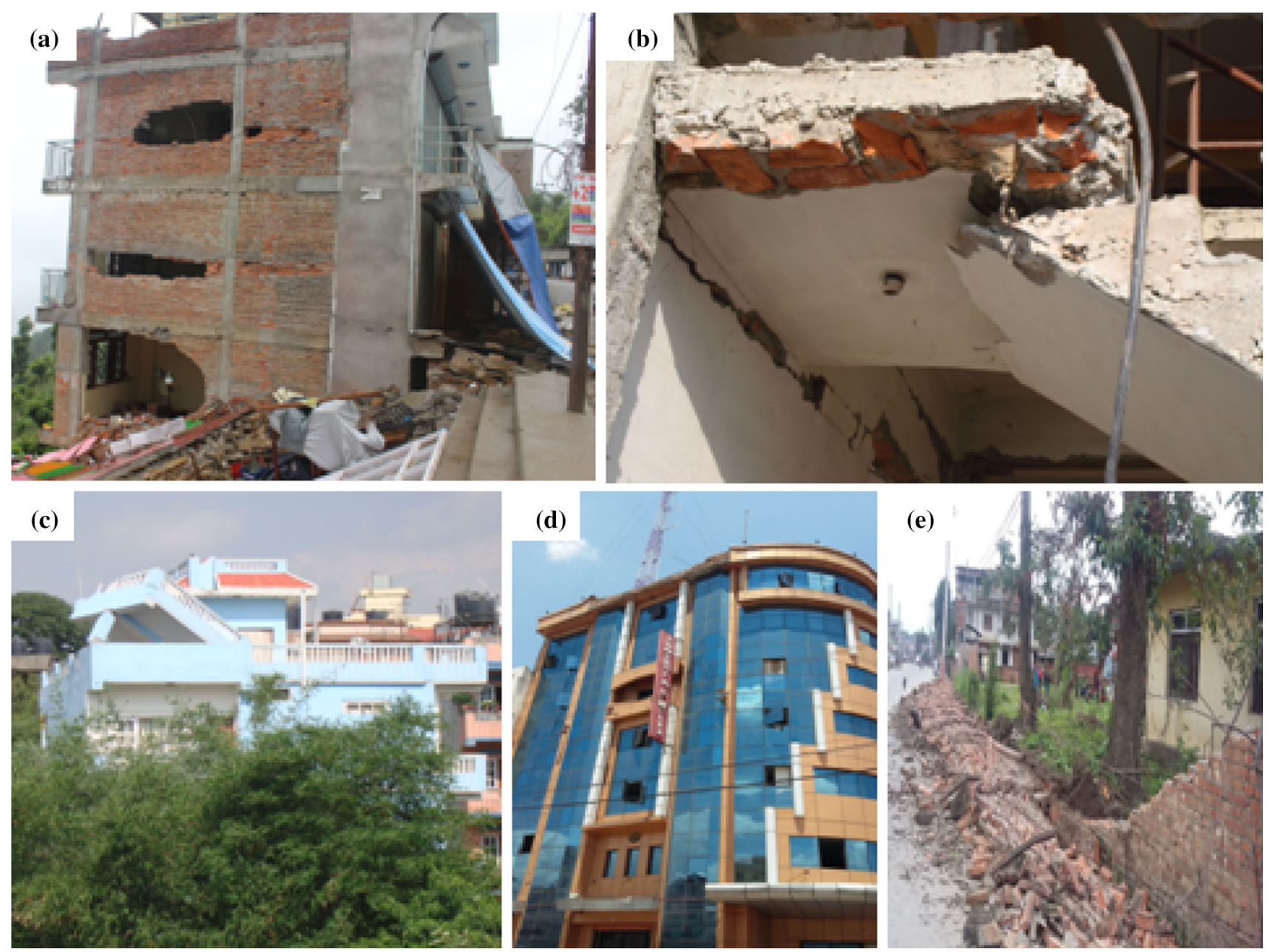

Fig. 8 a Out of plane collapse of brick infill wall in Chautara (Sindhupalchowk). b Damaged staircase. c Damaged water tank. d Damaged parapet wall in a high rise building. e Damaged boundary wall

was observed that the buildings constructed in river banks were facing rocking and sliding of foundation problem (Fig. 9c) even if the structural system was undamaged. Moreover, both foundations as well as structural deficiencies led building collapse were also noticed in some locations within Kathmandu valley (Fig. 9d).

\section{Soil investigation and foundation site selection}

Soil investigation before construction is not performed for residential buildings in Nepal. Even metropolitan cities, sub-metros and municipalities are not able to enforce mandatory geotechnical investigation before construction. The severely damaged areas of Sitapaila and Gongabu within Kathmandu metropolitan city have soil bearing capacities of 52 and $106 \mathrm{KN} / \mathrm{m}^{2}$ respectively. As per Nepal building code these sites are classified as weak to soft foundation types [2] though effective remedies weren't incorporated for building constructions and common construction system as of other areas in Kathmandu valley were found to be incorporated during building construction. Instead of foundation improvement, additional stories were constructed in weak columns of $0.23 \times 0.23 \mathrm{~m}$.

Due to lack of site specific design spectrum and localized design guidelines, construction practices are similar for all over Nepal. Though MRT is mandatory in many urban areas, most of the recently declared municipalities lack the basic earthquake resistant features in residential level. This has also triggered the intensity of damage in many newer urban centers and suburbs. The effect of topographic amplification, ridge effect and local site effects are clearly identified due to the more localized nature of damage during 2015 Gorkha earthquake.

\section{Construction and structural deficiencies and associated damages in URM buildings}

Most of the urban nuclei in Kathmandu valley and older settlements outside consists majority fraction of unreinforced masonry building stocks constructed from sun-burnt 

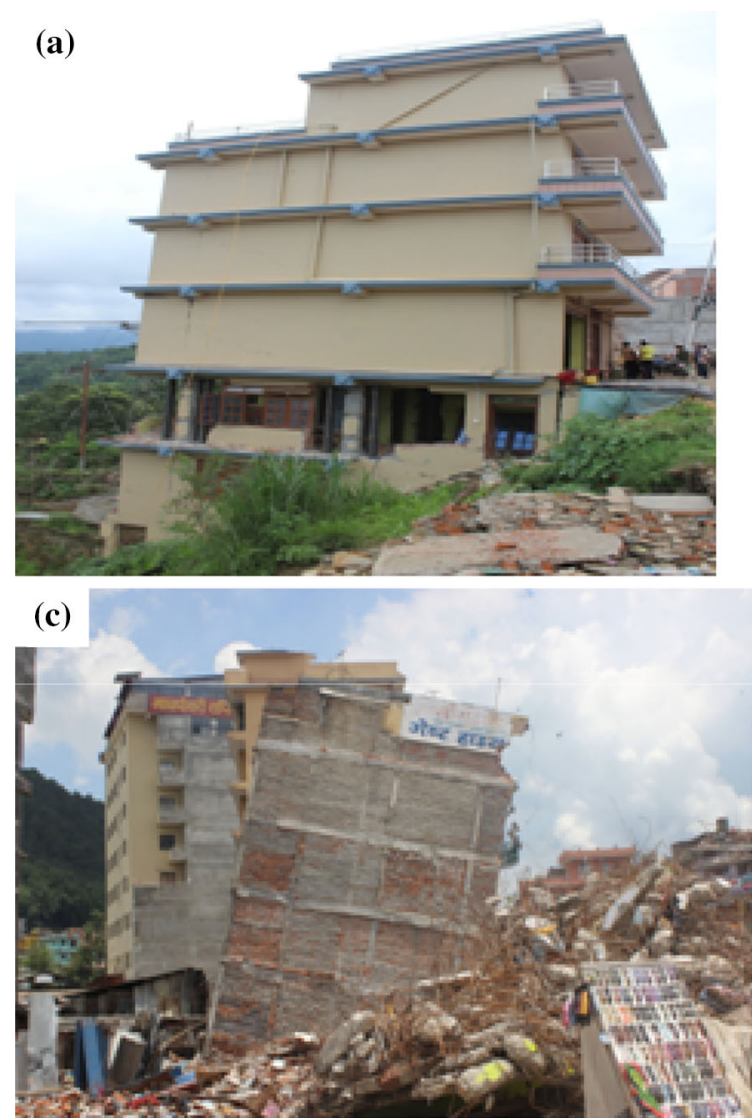

Fig. 9 a RC building in stepped foundation with partial damage. b Building tilted with column failure due to stepped foundation. c Large displacement in foundation led tilting of building constructed

or fired clay bricks. The common failure characteristics of masonry buildings interlinked with the analysis of structural and construction technology based deficiencies are disseminated in following sections.

\section{Structural integrity}

Almost all, except some URM buildings were found to be not consisting any bands at various levels like; sill, lintel or gable. Due to lack of proper bonding in masonry load bearing wall, out of plane collapse was more commonly observed in Kathmandu valley and other settlements with abundance of URM buildings (Fig. 10a). In most of the URM building, the orthogonal walls were found to be behaving differently due to lack of proper connection between such walls showing poor integrity. Also due to lack of integration of several members within the structural components, out of plane failures were more intense than any other type of failure (Fig. 10b). In case of masonry structures, due to poor quality of binding materials, delamination of wythes was also common in stone masonry houses outside Kathmandu valley (Fig. 10c), however such
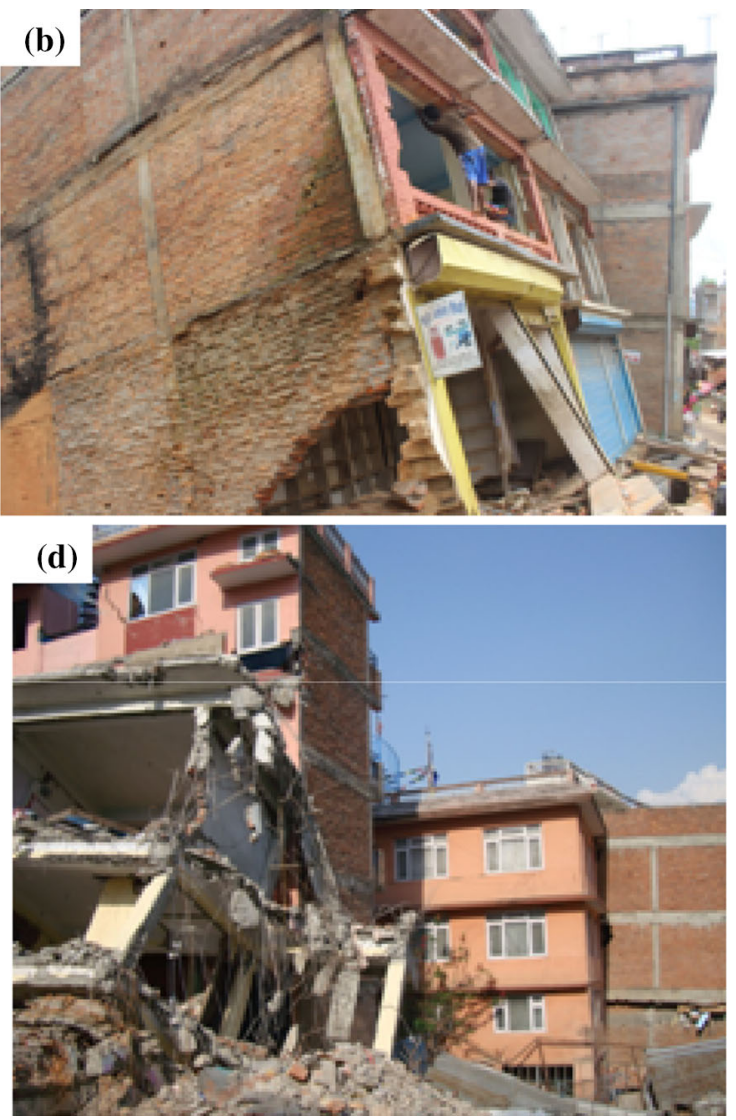

in river bank in Gongabu (Kathmandu). d Collapsed RC building in Kathmandu due to combination of foundation as well as structural deficiencies

delamination was also noticed in some thick walled constructions in Kathmandu valley monuments. Use of mudmortar or clay with high water quantity was noticed on some reconstruction efforts during field reconnaissance (Fig. 10d) this might significantly contribute in generating larger voids and poor binding of masonry units so as to contribute in delamination of wythes.

\section{Binding materials}

The structural integrity depends also on monolithic and homogenous behavior of masonry structures; however the mud mortar used for binding the brick/stone units were found to detached already and brick/stone units were found to be behaving separately (Fig. 11a). This binding problem led the severe devastation during 2015 Gorkha earthquake in the historic settlements of Kathmandu, Lalitpur, Bhaktapur, Sankhu, Harisiddi, Barpak, among others. Even after the earthquake damage people were found to be using the same binding material for reconstruction (Fig. 11b). This could be detrimental in future events. 

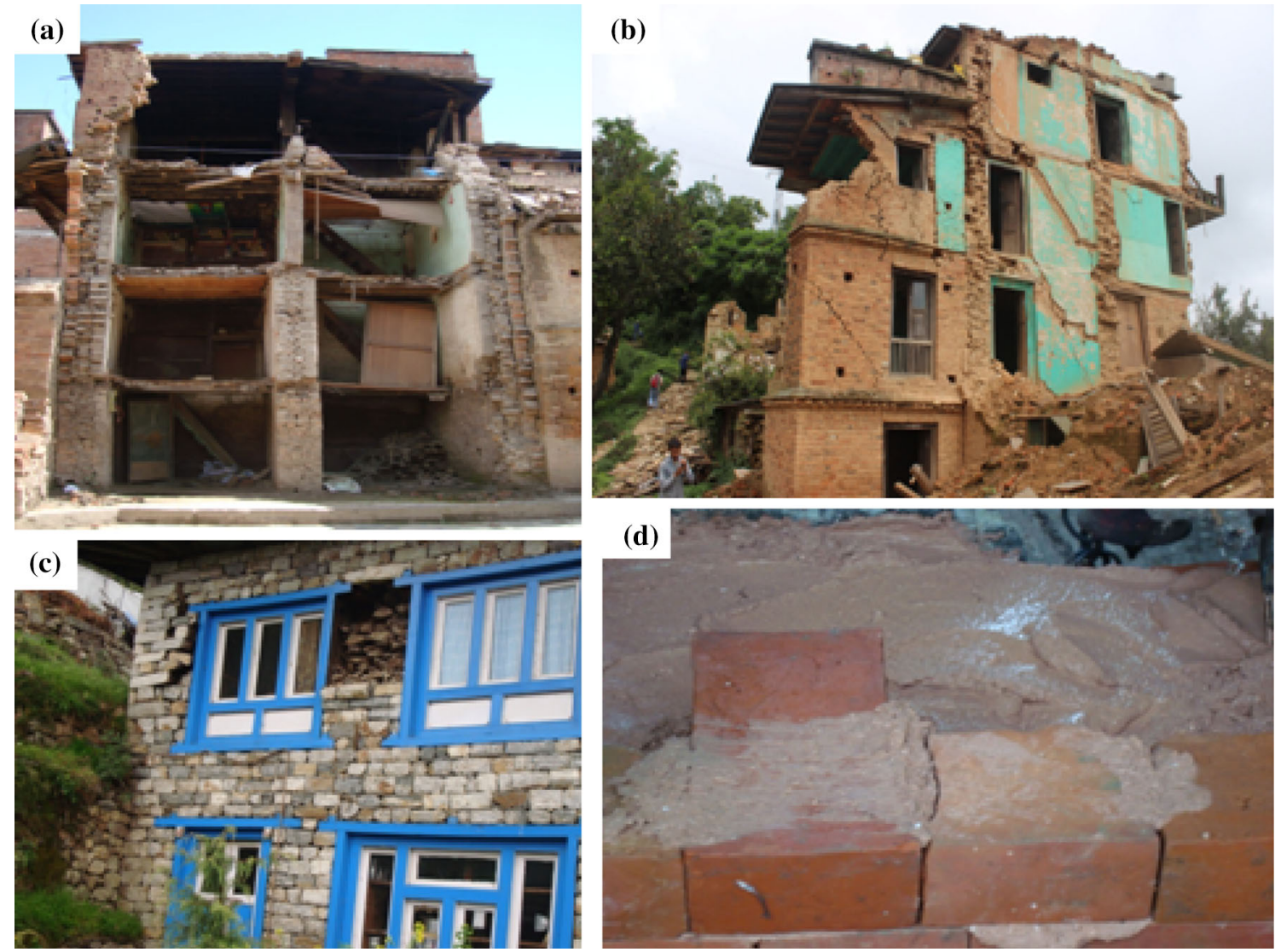

Fig. 10 a Out of plane collapse of load bearing masonry wall in Bhaktapur. b Heavily damaged masonry structure in Chautara due to out of plane collapse of majority of walls. c Delamination of wythes

observed in stone masonry wall in Solukhumbu (Everest base camp area). d Common practice of mortar placement for masonry construction

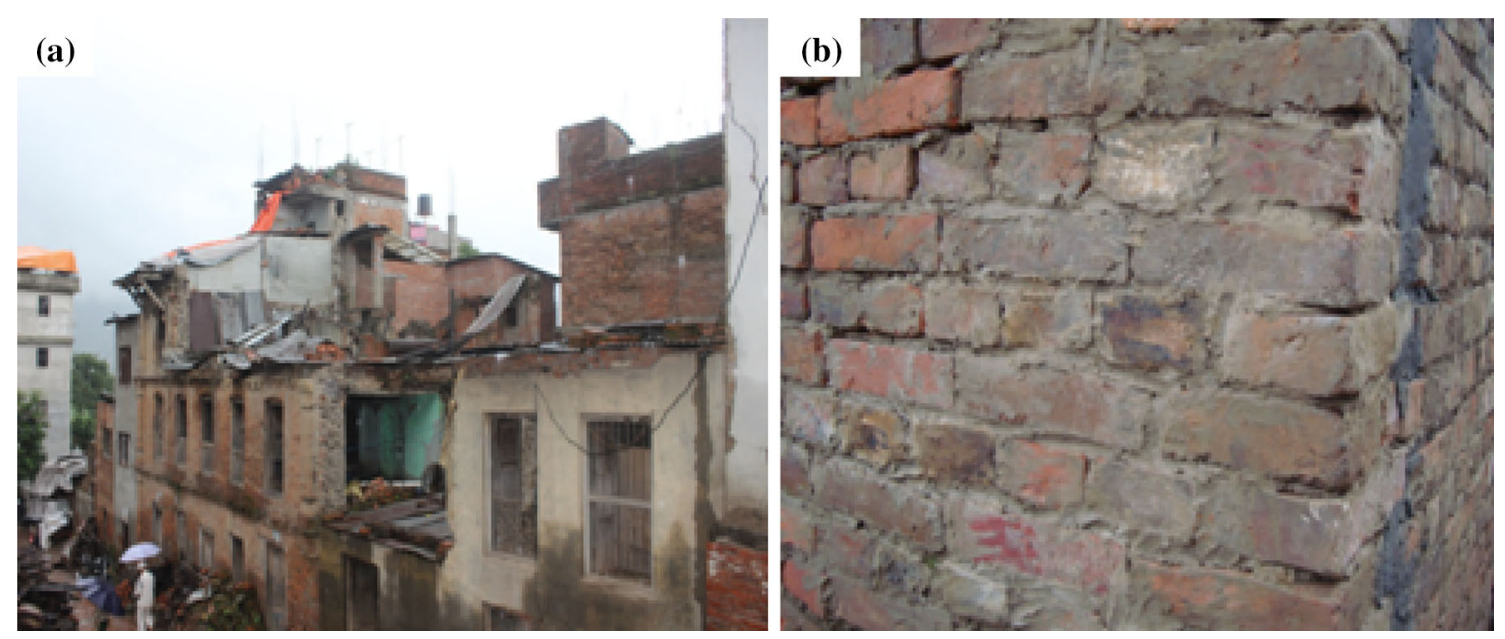

Fig. 11 a Failure of masonry units due to lack of proper binding. b Mud mortar used for reconstruction of URM building destroyed during 2015 Gorkha earthquake at Bhaktapur

\section{Load path discontinuity}

Due to mixed up system of construction and added reinforced concrete portions in upper stories along with cantilevered constructions, many of the buildings in Kathmandu valley were observed with load path discontinuity (Fig. 12a). The reentrant corners and diaphragm discontinuities were also noticed in masonry construction practices 

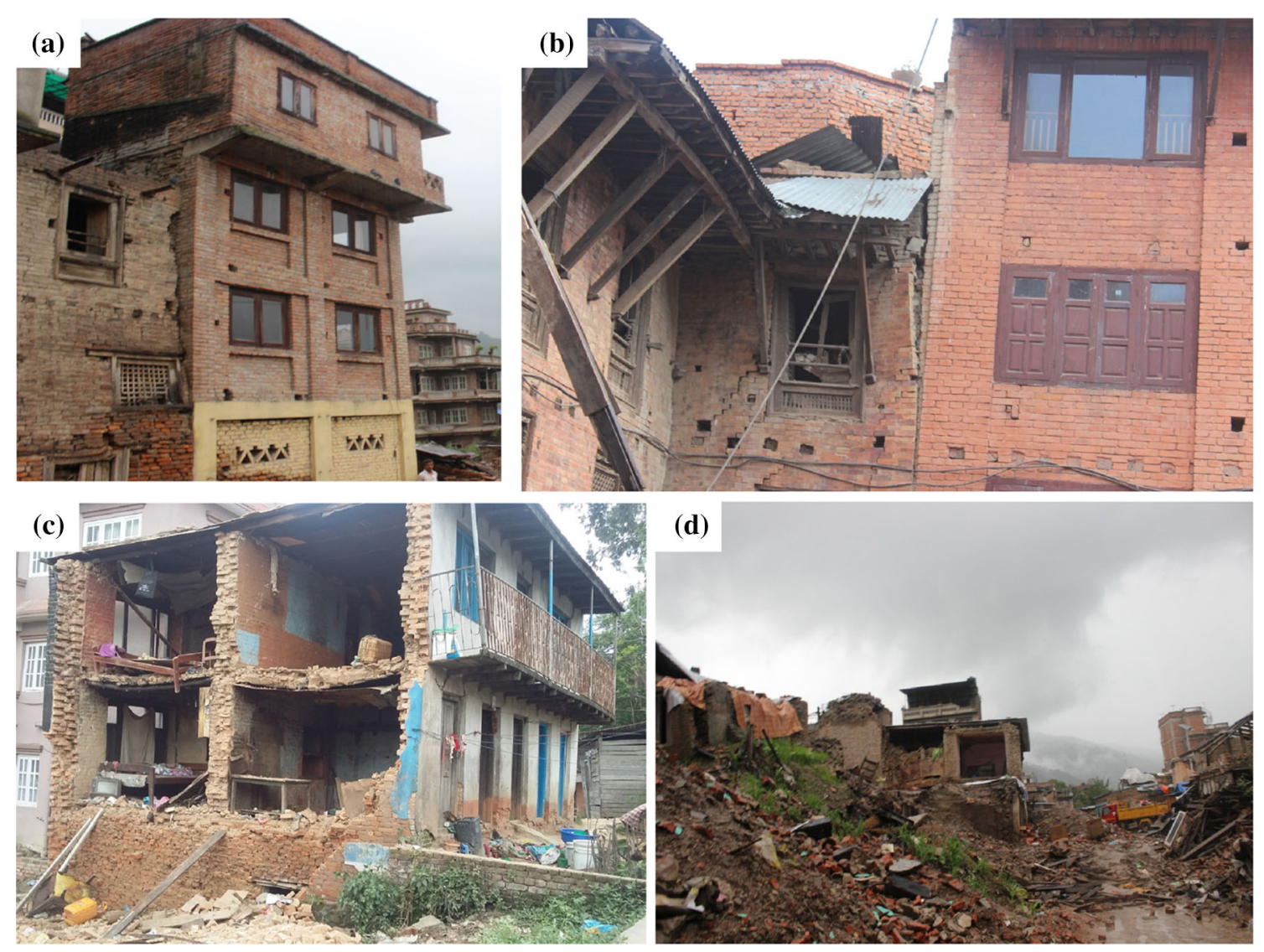

Fig. 12 a Heavy load concentration in the fourth storey of a masonry building. b Re-entrant corner and associated damage in masonry building in Bhaktapur. c Lack of connection led collapse of wall. d Heavy damage in old masonry houses in Sankhu

in Nepal (Fig. 12b). Masonry buildings up to six stories were found inside Kathmandu valley and in case of outside Kathmandu valley the number of stories for masonry buildings is limited to four. Struts in some masonry buildings performed the function of transferring the cantilevered load into structural wall [13], but majority of masonry structures were found to be without having struts even if the roofing was too heavy constructed with roof tiles.

\section{Connections}

The connection between walls, walls and floor and wall and roof was found to be poor in masonry buildings. In many buildings, it is found that due to weak connection and lack of corner post or stone, two orthogonal walls were found to be isolated leading to out of plane failure, evidently this type of failure was most prevalent in majority of damaged masonry houses (Fig. 12c). In case of timber elements used as flooring and load transfer components, those were found to be surviving even after the out of plane collapse of external walls. Several traditional practices to tie up the building elements like wooden pegs and wooden bands exist in Kathmandu valley [13] as well as throughout Nepal. However, those collapsed or severely damaged buildings seldom constituted such elements.

\section{Age of buildings}

Masonry buildings in Nepal during the 2015 Gorkha earthquake were up to of 100 years age used by at least three generations. Many of the building at Sankhu and Bhaktapur were of around 100 years of age and it is also noticed that majority of collapsed buildings were of 70-80 years old (Fig. 12d). Due to deterioration of strength, buildings were in vulnerable stage even before the earthquake. Aside from very old age of masonry buildings, it was noticed that none of the houses were strengthened or retrofitted after construction. All the damaged houses at least sustained some damages during the 1988 Uadypur earthquake, however houses weren't strengthened. Due to lack of repair and maintenance, most of the old houses were heavily damaged.

\section{Shared walls and wall thickness}

In case of traditional masonry constructions most of the urban fabrics with row housing were observed to be sharing walls in one or both side of walls and found to be damaged during 2015 Gorkha earthquake (Fig. 13a). Such practices were seen in the row housing system of traditional 

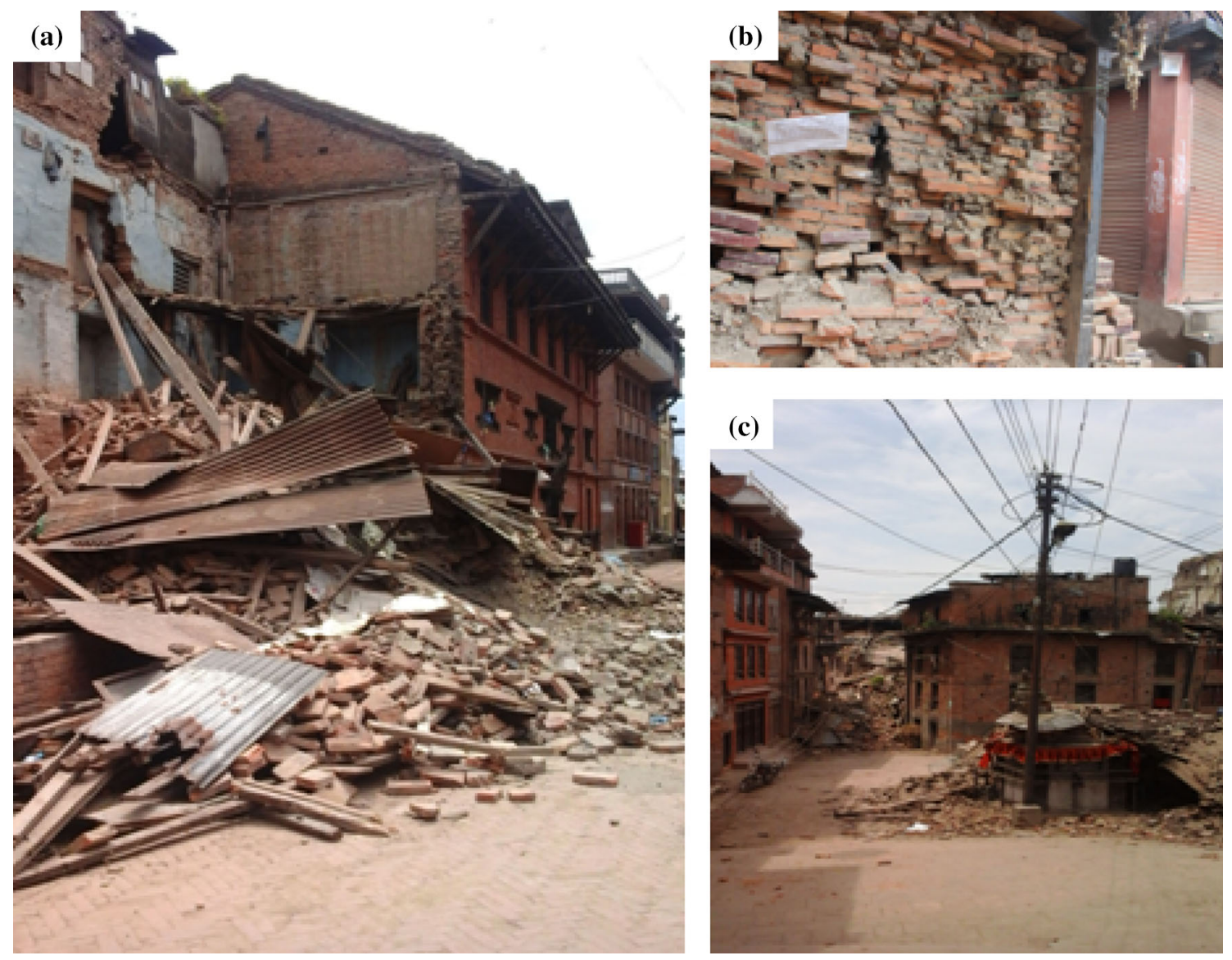

Fig. 13 a Damage in shared wall. b Segregated mud mortar and associated delamination of wythes. c Damaged building with inclined foundation and intact buildings having leveled foundation

settlement where single house is divided into two and phased construction or repair was done in either unit. The thickness of brick masonry wall was found up to $0.60 \mathrm{~m}$ but poorly connected with mud mortar. Such mud mortar binding was found to be detached from brick units many years back and delamintaion of wythes was commonly observed in those buildings with segregated mud mortar (Fig. 13b).

\section{Foundation problem}

Shallow and spread foundation is commonly adopted in masonry constructions in Nepal. Beside this, natural terrain was found to be adopted directly for foundations so that inclined foundations were commonly observed in majority of masonry buildings constructed across and outside Kathmandu valley. It is observed that the buildings resting on inclined foundations were more damaged than those buildings resting on leveled foundation (Fig. 13c).

\section{Heavy roofs}

In majority of the masonry construction in Nepal, roof tiles are commonly used as roofing materials with thick layer of mud mortar. Also in some masonry buildings in Kathmandu valley, RC slab was found to be used as roof and ultimate destruction was caused by such heavy load concentration in the third or fourth storey (Fig. 14a). The roofing materials are not also tied or anchored properly with other structural members and found to be severely damaged during reconnaissance.

The gable portion of most of the masonry buildings was found to be constructed with thick brick wall; this ultimately led to most of the gable portion failure (Fig. 14b). The performance of thick gable wall was weak throughout Nepal in stone masonry and brick masonry structures (Fig. 14b, c). Although, some areas used to have small to big gable openings, due to heavy concentration of stacked and unsupported masonry units, failure was commonly observed in central Nepal, eastern Nepal as well as inside Kathmandu valley. 

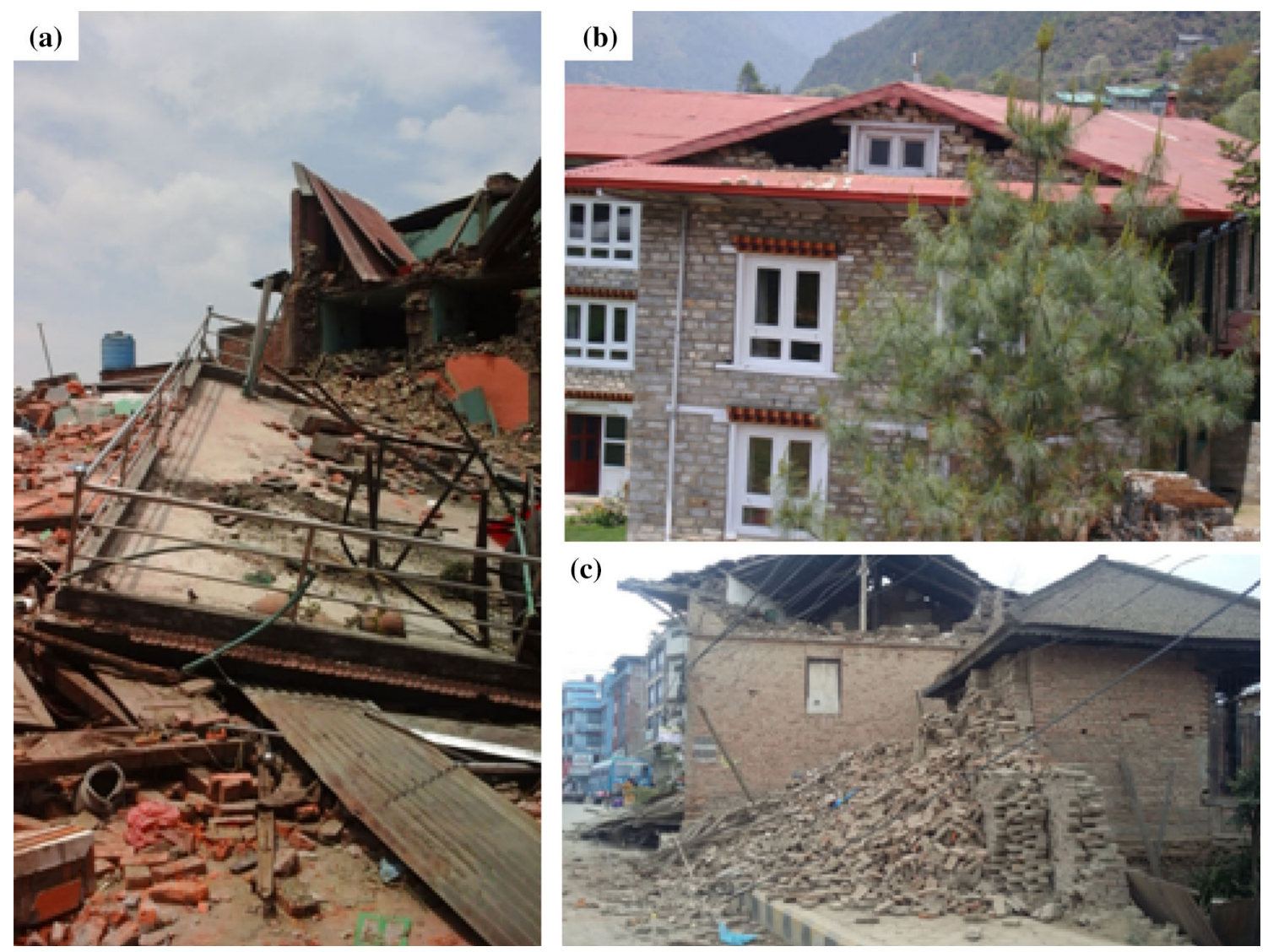

Fig. 14 a Complete collapse of RC slab used as roofing in a masonry building. b Out of plane failure of gable portion of a stone masonry building. $\mathbf{c}$ Heavy gable portion out of plane failure in brick masonry

\section{Diagonal bracing}

Due to lack of diagonal bracing in masonry constructions, most of the out of plane failure were common. Diagonal bracings are not practiced in Nepal in any form, thus structural integrity is seldom assured in owner built constructions as well historical and monumental constructions. The widespread damage in epicentral district of Barpak (Gorkha), Melamchi and Chautara (Sindhupalchowk), Mankhu (Dhading), Beshisahar (Lamjung), Dhunche (Rasuwa) and other areas were suffered from brittle collapse due to lack of diagonal or any type of bracing on walls.

\section{Pounding and progressive failure}

Most of the urban fabrics within Kathmandu valley consist row housing. In such housing framework, due to variation in dynamic properties of masonry units, pounding in terms of wall damage or bulging out of the wall was commonly observed within Kathmandu valley (Fig. 15a). The variations in storey height and construction materials and building components usually control the intensity of damage significantly.
Meanwhile, the masonry buildings on the edge of row housing setup were found to be more damaged than the buildings in between. The intensity of damage in case of row houses was observed to be higher in the buildings on edge for all settlements in central Nepal, however those masonry structures with wooden frames were not found to be completely collapsed like the stone or brick masonry load bearing system. Many of the masonry buildings in epicentral districts and areas with row houses were observed to be suffered from progressive failure mechanism.

\section{Construction and structural deficiencies and associated damages in random rubble masonry buildings}

Majority of the fraction of buildings in Nepal is comprised of dry stone masonry construction practice [3]. These are non-engineered constructions without following any earthquake resistant construction guideline and mud mortar is either used or sometimes constructed without mortar as well. In case of absence of mud mortar, the voids in between masonry units were found to be filled 

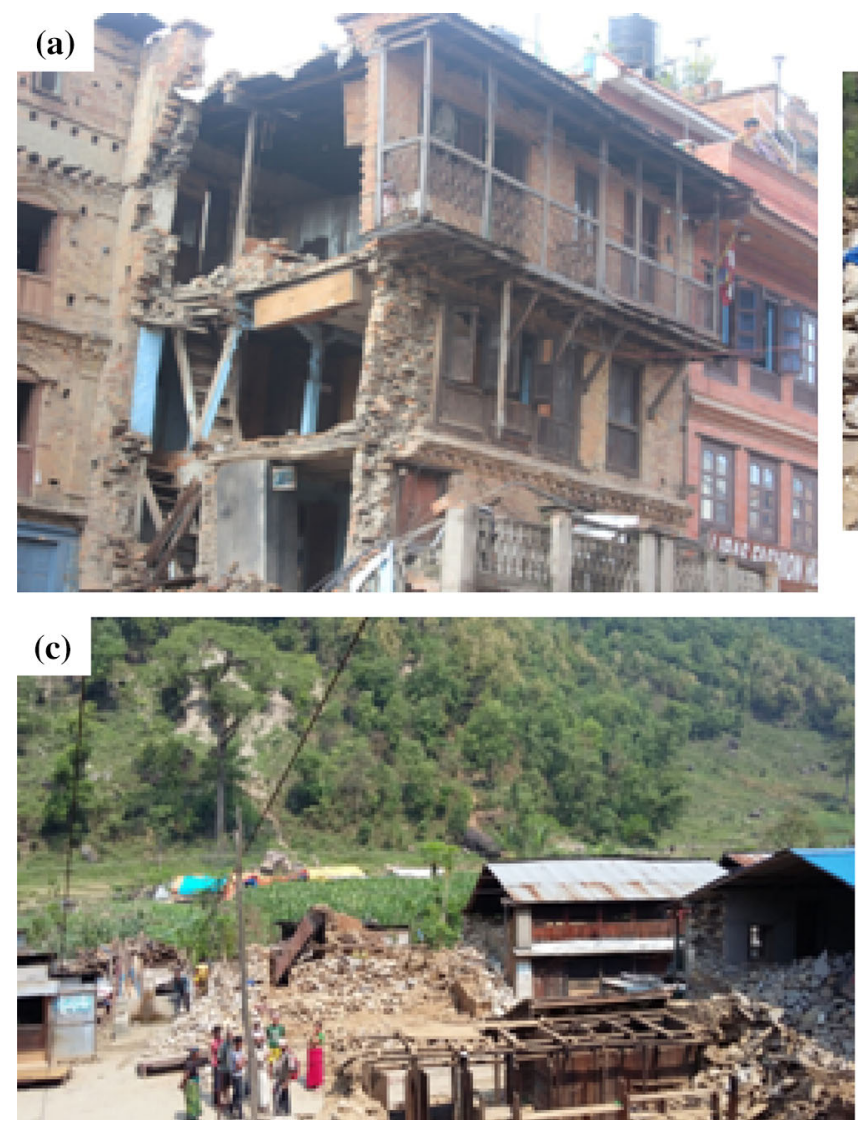
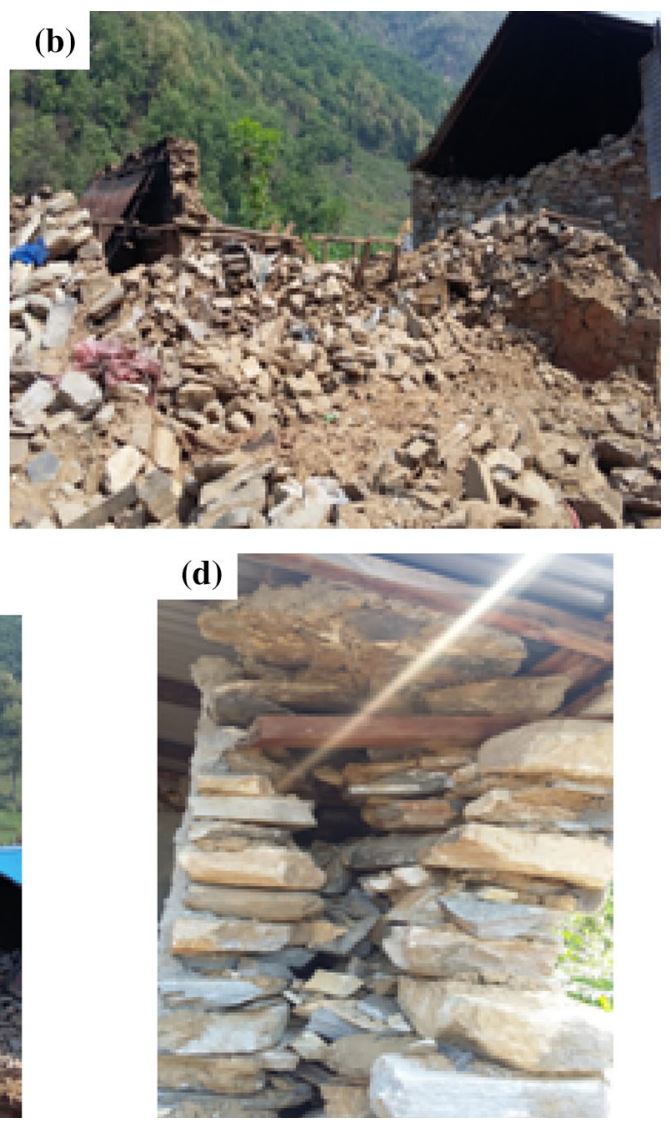

Fig. 15 a Pounding and progressive failure on the building situated on edge. b Complete collapse of row houses in Baluwa (near epicenter). c Progressive failure on row houses and good performance of timber frames. d Separated wall due to structural pounding

with stone chips or aggregates. Beside the irregular stones, in majority of houses, there were no cornerstones and even the shape of stone units was too irregular leading to heavy damage (Fig. 15b). Timber bands were seldom noticed in most of the damaged houses in all reconnaissance sites, however, in case of presence of timber framing those frames were found to be undamaged or sustaining very little damage (Fig. 15c). Mud mortar was found to be used in stone masonry buildings. Due to irregular shape of the stones the binding material was used variably, this may have contributed to the performance of buildings during earthquake. Smaller chips to heavy stone pieces were found to be used to construct walls, sometimes such arrangement itself was found to be triggering the pancake destruction houses due to lack of structural integrity. Those houses with timber elements were found to be less damaged than the homogenously constructed stone houses. Though rural constructions are isolated type building units with lower height, usually from one to three storied; yet deficiencies in terms of structural composition and construction technology were widely noticed during field reconnaissance. Heavy wall of rubble stones with irregular shape and size up to $0.53 \mathrm{~m}$ thick was observed (Fig. 15d). The stone masonry houses constructed with piling of stones were severely affected like in the epicentral village of Barpak (Fig. 16a). Beside this, very heavy roofs constructed from stone slices (Fig. 16b) were found to be dominant than any other roofing system in Barpak leading to severe collapse of houses.

\section{Construction and structural deficiencies and associated damages in adobe buildings}

Adobe buildings are also non-engineered constructions prevalent in many urban fabrics as well as in suburbs and villages in Nepal. Most of the adobe constructions constitute either handmade brick walls, walls mixed with clay and some bamboo elements or even sometimes clay units of irregular shapes. The roofing may be of tiles, thatched or sometimes stones as well. The structural integrity is not justified in adobe houses due to poor binding and nonhomogenous construction. Somehow, the components of construction behave separately rather than combined action against the earthquake motion. The roof if provided with tiles is also heavy thus damages were frequent in such 

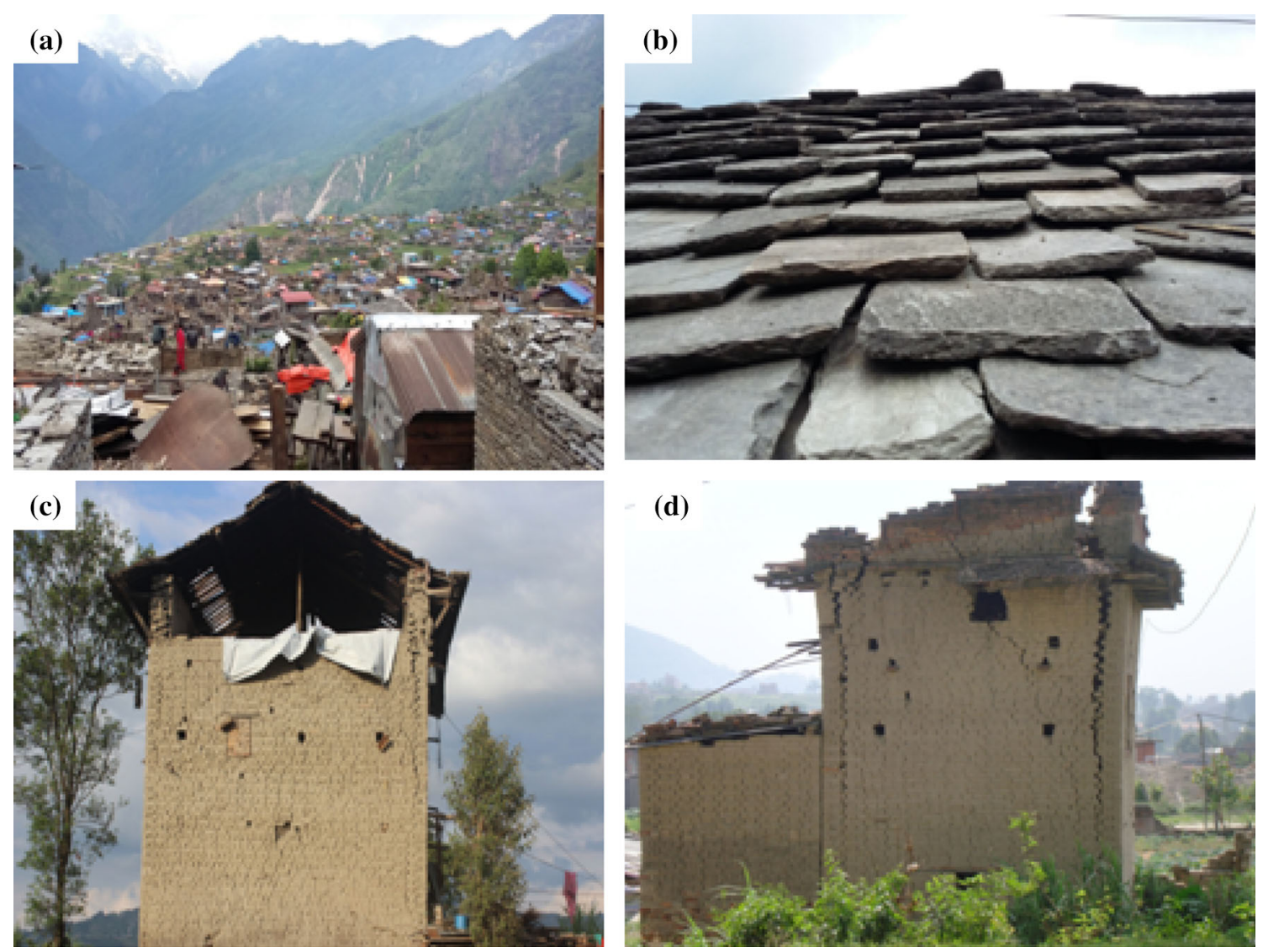

Fig. 16 a Heavily damaged neighborhood of Barpak village where 1250 houses out of 1450 total were collapsed. b Heavy stone roofing in Barpak. $\mathbf{c}$ Gable collapse in adobe house in Bhaktapur. d Separation of diagonal walls in an adobe house

houses during 2015 Gorkha earthquake. Adobe constructions are also found to be one to three storied and houses with more heights were found to be affected more than the single storied adobe houses. The primary damage mechanism was observed as complete collapse, gable collapse (Fig. 16c) and detachment of orthogonal walls (Fig. 16d). As recent construction technology seldom follows adobe construction system in Nepal, almost all structures were of old to very old age and also those structures sustained minor damage during 1988 Udaypur earthquake.

\section{Conclusion}

The Gorkha earthquake of 25 April 2015 reflected the performance of various types of buildings. After field reconnaissance in around 3500 buildings of various types, many types of construction as well as structural deficiencies were identified. The RC, URM, rubble stone construction and adobe construction were found to be the dominant construction systems of Nepal. The majority fraction of damage is found to be consisted by URM, rubble stone and adobe buildings of central and eastern
Nepal. Moreover, RC damage is found to be localized so many reasons except structural and construction deficiencies like liquefaction, local site effects, ground amplification, among others may have contributed in building damage. The common types of failures in RC construction were identified as the soft storey, pounding, shear failure, and other failures associated with construction as well as structural deficiencies like building symmetry, detailing and others. Moreover, for URM constructions, the structural integrity, heavy load accumulation, age, lack of bracing and pounding were the major cause of complete collapse or out of plane failure. Similarly, binding and structural integrity, lack of tying members, heavy gable and roof construction were the leading cause of damage in random rubble construction and adobe constructions.

About $95 \%$ damage is shared by URM, random rubble and adobe buildings, so this earthquake was more devastating towards such buildings in comparison to the performance of RC buildings in affected districts. All the damage was noticeably concentrated into non-engineered or pre-engineered buildings with major flaws in construction or structural components so it could be inferred that engineered constructions should be plausible solution for 
seismically active regions like Nepal. The wooden framed houses were the most survived structures that performed very well during 2015 Gorkha earthquake and this paradigm was well reflected during 1934 Bihar-Nepal and 1988 Udaypur earthquake as well $[4,11]$. It is imperative to understand and implement that, after every earthquake in Nepal, the existing structures are nevertheless strengthened thus the survivors in following earthquakes constitute largest fraction of damage [4, 5]. Proper site selection, geotechnical observations and site specific design spectra and by-laws could enhance the structural performance as suggested by the localized damage scenario in Nepal after 2015 Gorkha earthquake. Moreover, the limiting age for use of structure should be clearly demarcated with routine strengthening techniques. Due to lack of proper implementation of by-laws, MRT and other buildings codes along with poor construction monitoring mechanism, many structures in urban areas are found to be haphazardly constructed and piled up, such structures have enhanced the vulnerability, so it is direly needed to reframe the construction monitoring mechanism along with monitoring of ongoing changes in structures in terms of non-structural members. The common construction practice was found to be more adhered towards strong beam and weak column framework for owner built constructions in Nepal, so it would be crucial to enforce the building codes, ductile detailing and proper development length as well as anchorage strategies onwards. For the rural areas of Nepal, earthquake resistant technologies are needed to be propagated and capacity building in rural level is urgent so as to assure the performance local structures. As majority share of housing stock is non-engineered to poorly engineered, immediate strengthening frameworks are to be deployed immediately for reducing the vulnerability of structures.

Open Access This article is distributed under the terms of the Creative Commons Attribution 4.0 International License (http://crea tivecommons.org/licenses/by/4.0/), which permits unrestricted use, distribution, and reproduction in any medium, provided you give appropriate credit to the original author(s) and the source, provide a link to the Creative Commons license, and indicate if changes were made.

\section{References}

1. United States Geological Survey (USGS) (2015) http://earth quake.usgs.gov/earthquakes/eventpage/us20002926\#general_ summary

2. NBC (Nepal Building Code) (1994) Ministry of Physical Planning and Works, Government of Nepal (different volumes)

3. CBS (Central Bureau of Statistics) (2012) Nepal housing and population census, National Planning Commission, Government of Nepal

4. JSCE (Japanese Society of Civil Engineers) (1989) Reconnaissance report on the 21 August 1988 earthquake in the Nepal-India border region

5. Gautam D, Bhetwal KK, Rodrigues H, Neupane P, Sanada Y (2015) Observed damage patterns on buildings during 2015 Gorkha (Nepal) earthquake. In: Proceedings of 14th international symposium on new technologies for urban safety of mega cities in Asia, 29-31 October, Kathmandu, Nepal

6. Chaulagain H, Rodrigues H, Jara J, Spacone E, Varum H (2014) Seismic response of current RC buildings in Nepal: a comparative analysis of different design/construction. Eng Struct 49(2013):284-294

7. Chaulagain H, Rodrigues H, Silva V, Spacone E, Varum H (2015) Seismic risk assessment and hazard mapping in Nepal. Nat Hazards 78:583-602

8. Chaulagain H, Rodrigues H, Silva V, Spacone E, Varum H (2015) Earthquake loss estimation for the Kathmandu valley. Bull Earthquake Eng. doi:10.1007/s10518-015-9811-5

9. Dixit AM, Yatabe R, Dahal RK, Bhandary NP (2013) Initiatives for earthquake disaster risk management in the Kathmandu valley. Nat Hazards. doi:10.1007/s11069-013-0732-9

10. JICA (Japan International Cooperation Agency) (2002) The study on earthquake disaster mitigation in the Kathmandu valley kingdom of Nepal

11. Rana BSJB (1935) The great earthquake of Nepal. Jorganesh Press, Kathmandu

12. Angster S, Fielding E, Wesnousky S, Pierce I, Chamlagain D, Gautam D, Uprety BN, Kumahara Y, Nakata T (2015) Field reconnaissance after the April 25, 2015 M7.8 Gorkha earthquake. Seismol Res Lett 86(6):1506-1513

13. Gautam D, Rodrigues H (2015) Architectural and structural characteristics of indigenous Newari chhen: study of seismic risk and resilience in historic urban nucleus of Bhaktapur city, Nepal. In: Proceedings of 14th international symposium on new technologies for urban safety of mega cities in Asia, 29-31 October, Kathmandu, Nepal 